\title{
Intentional Carbofuran poisoning in 7 dogs
}

\author{
Dalma Pivariu', Adrian-Nechita Oros ${ }^{1}$, Flaviu Tabaran ${ }^{2 *}$ (D) Adrian Gal $^{3}$, Cristian Martonos ${ }^{3}$ and Andras-Laszlo Nagy ${ }^{1}$
}

\begin{abstract}
Background: Carbofuran is a widely used broad-spectrum pesticide that, despite strict regulation and being banned for more than a decade, is still encountered in cases of intentional poisoning in dogs and wildlife. The objective of the study was to provide a complete and detailed description of the pathological, histological and toxicological findings of 7 cases of intentional carbofuran poisoning in dogs.

Results: In this retrospective study, 7 cases of carbofuran intoxication recorded from July 2015 to June 2017 were analyzed. Following complete history recording, all cases were examined by complete necropsy and histopathology. Carbofuran intoxication was confirmed in all cases by gas chromatography. The postmortem examination revealed extensive hemorrhaging and congestion located mainly within the respiratory, nervous and cardiovascular systems, accompanied by degeneration and necrosis within the lungs, heart, and kidneys.

Conclusions: Although carbamates have been banned in the European Union, carbamate poisoning is still frequently encountered, especially in wild animals. This paper will contribute to a better understanding of the occurrence and pathogenesis of acute carbofuran exposure in dogs and contribute some peculiar pathological features of this type of poisoning to the current literature.
\end{abstract}

Keywords: Carbamates, Furadan, Pathology, Veterinary forensic medicine

\section{Background}

Carbofuran (2,3-dihydro-2,2-dimethyl-7 benzofuranyl methyl carbamate) is one of the most frequently encountered carbamates. It was used in agriculture from the 1970s [1] until it was banned on 31.12.2009 in the USA [2] and 05.12.2011 in Romania by the Law of Chemical Substances nr 254.

Furadan can still be sourced from several countries, such as Tanzania and Uganda. A recent survey indicated that carbofuran was readily available in approximately $80 \%$ of the sampled agro-veterinary supply stores in Uganda [3].

The most commonly marketed carbofurans were furadan, Bay 70,143, Curater, D 1221, Yaltox, Furacarb, and ENT 27164 $[4,5]$. Carbofuran is available in granular, liquid and powder formulations $[5,6]$ and was used in

\footnotetext{
* Correspondence: alexandru.tabaran@usamvcluj.ro

${ }^{2}$ Department of Veterinary Pathology, University of Agricultural Sciences and Veterinary Medicine, 3-5 Mănăștur Street, 400372 Cluj-Napoca, Romania Full list of author information is available at the end of the article
}

agriculture and forestry as a broad-spectrum systemic insecticide, nematicide and acaricide [3, 7].

Although this substance was banned almost 10 years ago, our cases show that it is still encountered in cases of intentional poisoning.

The main objective of this manuscript is to present the gross and histopathological findings of serial cases of carbofuran poisoning in dogs and the results of toxicological screening by GS-MS/MS of samples collected from deceased animals and to highlight the important contribution of such an analysis to criminal investigations.

Exposure to carbamates can occur by oral ingestion, inhalation or dermal absorption. Given the high toxicity of carbamates, any usage errors regarding mixing or storage of this substance can lead to intoxication.

The oral LD50 is approximately $3-19 \mathrm{mg} / \mathrm{kg}$ of body weight in different animal species [8]. The oral LD50 for dogs is $19 \mathrm{mg} / \mathrm{kg}$, and the LC50 for inhalation is $52 \mathrm{mg} /$ $\mathrm{kg}$ [9]. Young animals can be intoxicated by a lower dose than that required for adults because of their 
underdeveloped enzymatic system [10]. Repeated exposure, such as frequent spraying, can also cause intoxication. Animals can also be intoxicated by licking an empty container.

Carbofuran is metabolized into 3-hydroxycarbofuran and 3-cetocarbofuran, two highly toxic metabolites. The metabolism of carbamates in organisms is fast, and a large portion of metabolic activation and detoxification occurs in the liver. Excretion of metabolites occurs through the urinary and digestive tract and residues can be detected in feces, saliva and milk [11]. Vomit and/or diarrheic contents may be found near the animal in addition to remaining poisoned food $[12,13]$.

In animals, necropsies are performed by veterinary pathologists or veterinary general practitioners; these individuals should be made aware of the possible circumstances that led to the carbofuran-related death of the animal and follow established protocols, both for necropsy and sampling for toxicology. A toxicologist should always be consulted about the appropriate matrices according to the pathologist's suspicions, as well as the best methods for handling the samples, to obtain consistent and reliable results [14-19].

The majority of animals fatally poisoned by carbamates usually present nonspecific gross and histopathological findings [20,21], such as systemic congestion and multiple areas of hemorrhage [22-24].

\section{Results}

The toxicological examination employing gas chromatography established the diagnosis; carbofuran was detected in all of the cases.

The pathological findings for each case are presented separately in Table 1 , and we describe the most relevant gross and histopathological findings following carbofuran intoxication below.

External examination of the body revealed dried saliva around the oral cavity and a pink color around the mouth (Fig. 1-b) and on some parts of the body, usually on the lateral parts where the animal may have touched its fur with its mouth (Fig. 1-c). In four dogs, we found epistaxis.

In the eyes, we noticed multifocal 3rd-eyelid hemorrhaging associated with diffuse uveal congestion and hyphema (unilateral or bilateral) (Fig. 1-d, e).

In three dogs, subcutaneous and muscular hemorrhages were present.

Generally, the gastric content was composed of an unknown pink-colored foreign substance mixed with bread or meat, chicken parts, or even feathers. In the pharynx and esophagus, pink coloration of the mucosa was noted. The small intestine and its content were also colored pink. Additionally, microhemorrhages were observed in the colon.
Histology revealed that the stomach mucosa had desquamation and catarrhal inflammatory lesions, mainly involving the superficial epithelium, and congestion in the deep part of the lamina propria and submucosa.

One dog presented diffuse, acute, and minimal hepatic congestion, and another dog had diffuse splenic congestion.

Necropsy revealed hemorrhagic pericardial content and, in some cases, subendocardial congestion (Fig. 2a) and hemorrhage in the cardiovascular system. In the myocardium, diffuse congestion (Fig. 2-b) and hemorrhage were observed. In the myocardium of one particular individual, the myocardial fibers were replaced by fibrous tissue, with some atrophied myofibers sequestrated in the scar tissue, which could be the consequence of a chronic myocardial infarct.

In the upper respiratory tract, the larynx and trachea had diffuse congestion, and the lungs in most of the cases showed acute, severe, diffuse, bilateral pulmonary congestion and edema (Fig. 3-a), with multifocal petechial and ecchymosis.

Histologically, severe vascular changes, such as septal congestion (Fig. 3-c) associated with the presence of numerous siderocytes and diffuse edema in the alveoli, bronchioles and bronchi, were detected in the lungs (Fig. 3-b).

In the brain, the main findings were bilateral meningeal and cerebral acute congestion (Fig. 4a) with occasional petechiae. Histologically, the main changes observed in the brain were represented by cerebral congestion and gliosis, including the presence of glial nodules and discrete vascular cuffing (margination), mainly with lymphocytes. Additionally, some neurons presented a dark brown material (most likely lipofuscin) in the cytoplasm. The lepto-meningeal blood vessels presented congestion associated with local edema (Fig. 4.-b).

Bilateral, diffuse renal congestion accompanied by tubular degeneration and necrosis was recorded in all cases. Histologically, cortical-medullar congestion (Fig. 4-c), vacuolar degeneration of the epithelium of the renal cortical tubules (Fig. 4-d), congestion of the glomerular tuft and Bowman's capsule thickening associated with the presence of a proteinaceous (hyaline) material in the urinary space were found.

\section{Discussion}

The residential and industrial use of carbamate and organophosphate pesticides is widespread in the United States. According to the US Environmental Protection Agency in 1997, over 40 organophosphate pesticides and 22 carbamate pesticides were included in the list of 900 pesticides that posed the highest risks to human health and were registered for use in the United States [25]. Both organophosphate and carbamate pesticides primarily target the nervous system of insects. Because of the structural similarities with the 
Table 1 Postmortem necropsy findings

\begin{tabular}{|c|c|c|c|c|c|c|c|}
\hline $\begin{array}{l}\text { Case } \\
\mathrm{Nr}\end{array}$ & External & Musculo-scheletal & Gastrointestinal and liver & Cardiovascular & Respiratory & Urinary & $\begin{array}{l}\text { Central } \\
\text { nervous } \\
\text { System }\end{array}$ \\
\hline I & $\begin{array}{l}\text { Pink colored } \\
\text { foreign } \\
\text { substance } \\
\text { (abundant) } \\
\text { staying the fur } \\
\text { around the } \\
\text { mouth and } \\
\text { muzzle }\end{array}$ & No significant findings & $\begin{array}{l}\text { Pink colored foreign } \\
\text { substance (abundant) } \\
\text { staying the Gl content } \\
\text { (mainly bread) and mucosa } \\
\text { of the upper Gl } \\
\text { Diffuse, acute, minimal } \\
\text { hepatic congestion }\end{array}$ & $\begin{array}{l}\text { No significant } \\
\text { findings }\end{array}$ & $\begin{array}{l}\text { Congestion and acute } \\
\text { pulmonary edema (diffuse, } \\
\text { acute) }\end{array}$ & $\begin{array}{l}\text { Renal severe } \\
\text { congestion, } \\
\text { cortical- } \\
\text { tubular } \\
\text { necrosis } \\
\text { (bilateral, } \\
\text { diffuse, } \\
\text { severe) }\end{array}$ & $\begin{array}{l}\text { Meningeal } \\
\text { cerebral } \\
\text { congestion } \\
\text { (diffuse, mild) }\end{array}$ \\
\hline II & $\begin{array}{l}\text { Pink-coloring the } \\
\text { fur around the } \\
\text { muzzle and on } \\
\text { parts of the fur } \\
\text { with a pink } \\
\text { substance } \\
\text { Conjunctiva } \\
\text { hemorrhage of } \\
\text { the third eyelid, } \\
\text { acute, severe } \\
\text { bilateral } \\
\text { hyphema }\end{array}$ & $\begin{array}{l}\text { Thoracic-cervical } \\
\text { muscular and } \\
\text { subcutaneous } \\
\text { hemorrhages, petechial } \\
\text { and ecchymosis } \\
\text { (associated with } \\
\text { hemorrhagic lymph } \\
\text { nodes) } \\
\text { Hemorrhagic joint fluid }\end{array}$ & $\begin{array}{l}\text { Pink colored foreign } \\
\text { substance admixed with } \\
\text { chicken meat, feathers and } \\
\text { corn within the pharynx, } \\
\text { esophagus and stomach } \\
\text { Diffuse gastric and small } \\
\text { intestinal congestion }\end{array}$ & $\begin{array}{l}\text { Hemorrhagic } \\
\text { pericardial content }\end{array}$ & $\begin{array}{l}\text { Trachea: diffuse congestion } \\
\text { (severe) } \\
\text { Parietal sub pleural } \\
\text { hemorrhages, } \\
\text { Lung: Bilateral, multifocal- } \\
\text { coalescing (ecchymosis) } \\
\text { pulmonary acute hemor- } \\
\text { rhages, with diffuse conges- } \\
\text { tion and edema (severe); }\end{array}$ & $\begin{array}{l}\text { Renal } \\
\text { Congestion; } \\
\text { Urinary } \\
\text { bladder: sub } \\
\text { mucosal } \\
\text { ecchymosis }\end{array}$ & $\begin{array}{l}\text { Meningeal } \\
\text { cerebral } \\
\text { congestion } \\
\text { and } \\
\text { hemorrhage, } \\
\text { diffuse, } \\
\text { bilateral, acute, } \\
\text { severe }\end{array}$ \\
\hline III & $\begin{array}{l}\text { Unilateral bulbar } \\
\text { conjunctiva } \\
\text { congestion }\end{array}$ & No significant findings & $\begin{array}{l}\text { Pharynx diffuse congestion } \\
\text { and edema } \\
\text { Oral, esophageal and gastric } \\
\text { contents with pink chicken } \\
\text { carcass residue } \\
\text { Focal small intestinal } \\
\text { hemorrhages (trans mural) }\end{array}$ & $\begin{array}{l}\text { Hemorrhagic } \\
\text { pericardial content } \\
\text { Aortic valvular diffuse } \\
\text { edema }\end{array}$ & $\begin{array}{l}\text { Larynx and trachea: diffuse } \\
\text { congestion (severe) } \\
\text { Acute, severe, bilateral } \\
\text { pulmonary congestion and } \\
\text { edema of the bronchi and } \\
\text { trachea }\end{array}$ & $\begin{array}{l}\text { Multifocal } \\
\text { perivascular } \\
\text { cortico- } \\
\text { medullary } \\
\text { hemorrhages }\end{array}$ & $\begin{array}{l}\text { Meningeal } \\
\text { cerebral } \\
\text { congestion }\end{array}$ \\
\hline IV & $\begin{array}{l}\text { Pink coloring of } \\
\text { the fur Severe, } \\
\text { unilateral } \\
\text { hyphema, } \\
\text { Epistaxis }\end{array}$ & No significant findings & $\begin{array}{l}\text { Pharyngeal, Esophageal and } \\
\text { gastric contents of chicken } \\
\text { carcass debris soaked in a } \\
\text { pink substance } \\
\text { Externally expressed lower } \\
\text { digestive (colon) } \\
\text { hemorrhages }\end{array}$ & $\begin{array}{l}\text { No significant } \\
\text { findings }\end{array}$ & Pulmonary edema & $\begin{array}{l}\text { Sub mucosal } \\
\text { hemorrhages } \\
\text { (paint brush) } \\
\text { Congestion }\end{array}$ & Congestion \\
\hline V & $\begin{array}{l}\text { Pink bright } \\
\text { substance on the } \\
\text { fur and muzzle } \\
\text { Severe, acute, } \\
\text { bilateral } \\
\text { hyphema } \\
\text { Epistaxis }\end{array}$ & No significant findings & $\begin{array}{l}\text { Gastric pink food contenting } \\
\text { the oral cavity on the } \\
\text { esophageal level } \\
\text { Gastro intestinal and splenic } \\
\text { diffuse congestion }\end{array}$ & $\begin{array}{l}\text { Pericardial } \\
\text { hemorrhagic content }\end{array}$ & $\begin{array}{l}\text { Acute, severe, bilateral } \\
\text { pulmonary hemorrhages, } \\
\text { confluent suffusions, edema } \\
\text { in the main bronchi and } \\
\text { trachea }\end{array}$ & $\begin{array}{l}\text { Sub mucosal } \\
\text { multifocal } \\
\text { congestion } \\
\text { (minimal) }\end{array}$ & $\begin{array}{l}\text { Acute, bilateral, } \\
\text { diffuse } \\
\text { meningeal } \\
\text { cerebral } \\
\text { hemorrhage } \\
\text { Diffuse brain } \\
\text { edema }\end{array}$ \\
\hline VI & $\begin{array}{l}\text { Foamy salivation, } \\
\text { epistaxis, oral } \\
\text { cavity } \\
\text { hemorrhages, } \\
\text { diffuse uveal } \\
\text { congestion and } \\
\text { hyphema }\end{array}$ & $\begin{array}{l}\text { Acute muscular } \\
\text { hemorrhages, axillary } \\
\text { area }\end{array}$ & $\begin{array}{l}\text { Pink colored foreign } \\
\text { substance (abundant) } \\
\text { staying the gastric and } \\
\text { duodenal content (bread) } \\
\text { and mucosa }\end{array}$ & $\begin{array}{l}\text { Subepicardial } \\
\text { congestion, and sub } \\
\text { endocardia } \\
\text { hemorrhages } \\
\text { (suffusions) (RV and } \\
\text { A); aortic valvular } \\
\text { diffuse edema }\end{array}$ & $\begin{array}{l}\text { Trachea: diffuse congestion } \\
\text { (severe) } \\
\text { Lung: Multifocal-coalescing } \\
\text { (ecchymosis) pulmonary } \\
\text { acute hemorrhages, with } \\
\text { diffuse congestion and } \\
\text { edema (severe); diffuse al- } \\
\text { veolar emphysema }\end{array}$ & Congestion & $\begin{array}{l}\text { Meningeal } \\
\text { congestion } \\
\text { (diffuse, mild) }\end{array}$ \\
\hline VII & $\begin{array}{l}\text { Epistaxis, diffuse } \\
\text { uveal congestion } \\
\text { and hyphema }\end{array}$ & $\begin{array}{l}\text { Acute muscular } \\
\text { hemorrhages thoracic- } \\
\text { abdominal and lumbar } \\
\text { (massive) }\end{array}$ & $\begin{array}{l}\text { Gastric mucosa congestion } \\
\text { (diffuse); gastric content- } \\
\text { plastic (possible carbofuran } \\
\text { container) admixed with } \\
\text { meat (presumably bite), hair, } \\
\text { grass and blood }\end{array}$ & $\begin{array}{l}\text { Subepicardial } \\
\text { hemorrhages } \\
\text { (ecchymosis); } \\
\text { Hemorrhagic } \\
\text { pericardial content }\end{array}$ & $\begin{array}{l}\text { Trachea: diffuse congestion } \\
\text { (severe) } \\
\text { Lung: Multifocal } \\
\text { (ecchymosis) pulmonary } \\
\text { acute hemorrhages diffuse } \\
\text { congestion and edema } \\
\text { (severe); focal emphysema }\end{array}$ & - & $\begin{array}{l}\text { Meningeal } \\
\text { congestion } \\
\text { and edema } \\
\text { (diffuse, } \\
\text { severe) }\end{array}$ \\
\hline
\end{tabular}

physiologically-active biomolecules, carbamates are synapticrelease blockers of the acetylcholinesterase (AChE). By this competitive-inhibitor mechanism, carbamates determine the excessive synaptic accumulation of acetylcholine (ACh) and disrupt the transmission of the neurological impulse, leading to the clinical signs associated with cholinergic toxicity. Physostigmine (eserine alkaloid), and organophosphates are additional examples of reversible and respectively irreversible cholinesterase inhibitors $[11,25]$.
In addition to neurological deficiency, neurodegeneration, endocrine disruption, and oncogenesis, organophosphates and carbamates can induce, whether directly or indirectly, extensive toxic effects in several systems as cardiovascular, respiratory, immune, urinary, reproductive, musculoskeletal, and cutaneous [25].

Carbofuran (furadan) is still causing intoxication in animals even after almost a decade of being banned [26]. Illegal poisoning of wildlife and domestic animals is a 

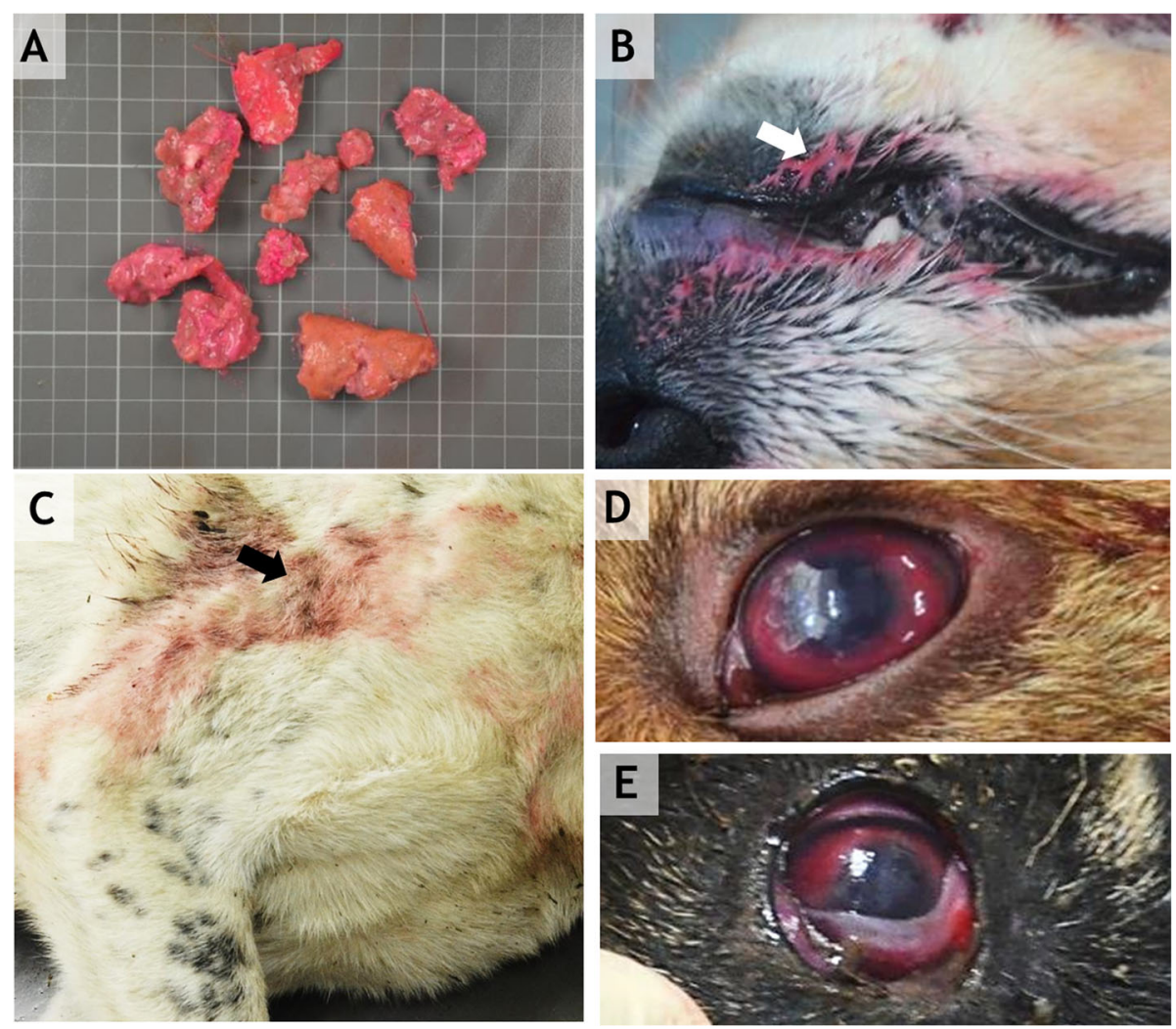

Fig. 1 a: The bait showing abundant pink liquid. $\mathbf{b}$ and $\mathbf{c}$ : A pink liquid (presumptively furadan) staining the fur around the mouth and thorax. $\mathbf{d}$ : Diffuse uveal congestion and hyphema. e: Multifocal 3rd-eyelid hemorrhages

worldwide issue [23]. There are high numbers of carbofuran poisoning incidents in birds. Novotny et al. [23] found sporadic cases of small carnivore intoxication, and martens and foxes are thought to be the main object of poisoners. Additionally, domesticated animals, such as pets, mainly dogs, and livestock, are at risk of being poisoned with carbofuran [8]. The clinical signs of accidental or intentional carbamate poisoning are nonspecific, reflecting a combination of muscarinic and nicotinic hyperstimulation [11].

Carbamates are reversible AChE inhibitors derived from carbamic acid. Carbamate causes inhibition of the activity of AChE, which is an enzyme responsible for the hydrolysis of the neurotransmitter acetylcholine in two separate components: choline and acetic acid [27, 28]. This results in an excess of acetylcholine in the synaptic cleft and prolonged binding to postsynaptic receptors [29]. AChE inhibition causes hyperstimulation of cholinergic receptors, followed by muscarinic, nicotinic and central nervous signs. AChE inhibitors may also impair endothelial function due to their toxicity to endothelial cells $[30,31]$ and the vascular wall [31]. The overstimulation of the somatic nervous system usually results in tremors, muscle twitches, and piloerection, as well as ataxia and paresis. Cholinergic tracts can be important to both autonomic parasympathetic and sympathetic systems but mostly influences the parasympathetic roots, transmitting impulses from the autonomic ganglia to all major organs of the body [3].

Systemic effects may occur within 30-60 min, generally occur after $6 \mathrm{~h}$, and rarely occur after $12 \mathrm{~h}$. Muscarinic symptoms are usually associated with salivation, lacrimation, urination, diarrhea, and gastroenteritis (SLUDGE) in addition to bradycardia, dyspnea, and miosis. Local effects usually occur because of direct contact with the product. Symptoms can be observed after a few minutes or can be delayed several days in the case of cutaneous exposure [32].

Intoxication with a cholinesterase inhibitor may lead to apparently opposite clinical signs, such as either constriction or dilation of the pupils or a speeding up or slowing down of the heartbeat.

The autonomic nervous system is subjected to constant adjustment through feedback mechanisms, and because of this, each individual may react differently to various levels of cholinergic stimulation. Death usually occurs due to respiratory failure and cardiac arrest [7].

The 7 cases described here are a clear example of carbofuran used for the intentional poisoning of dogs. In most of these confirmed cases, the results were used by 

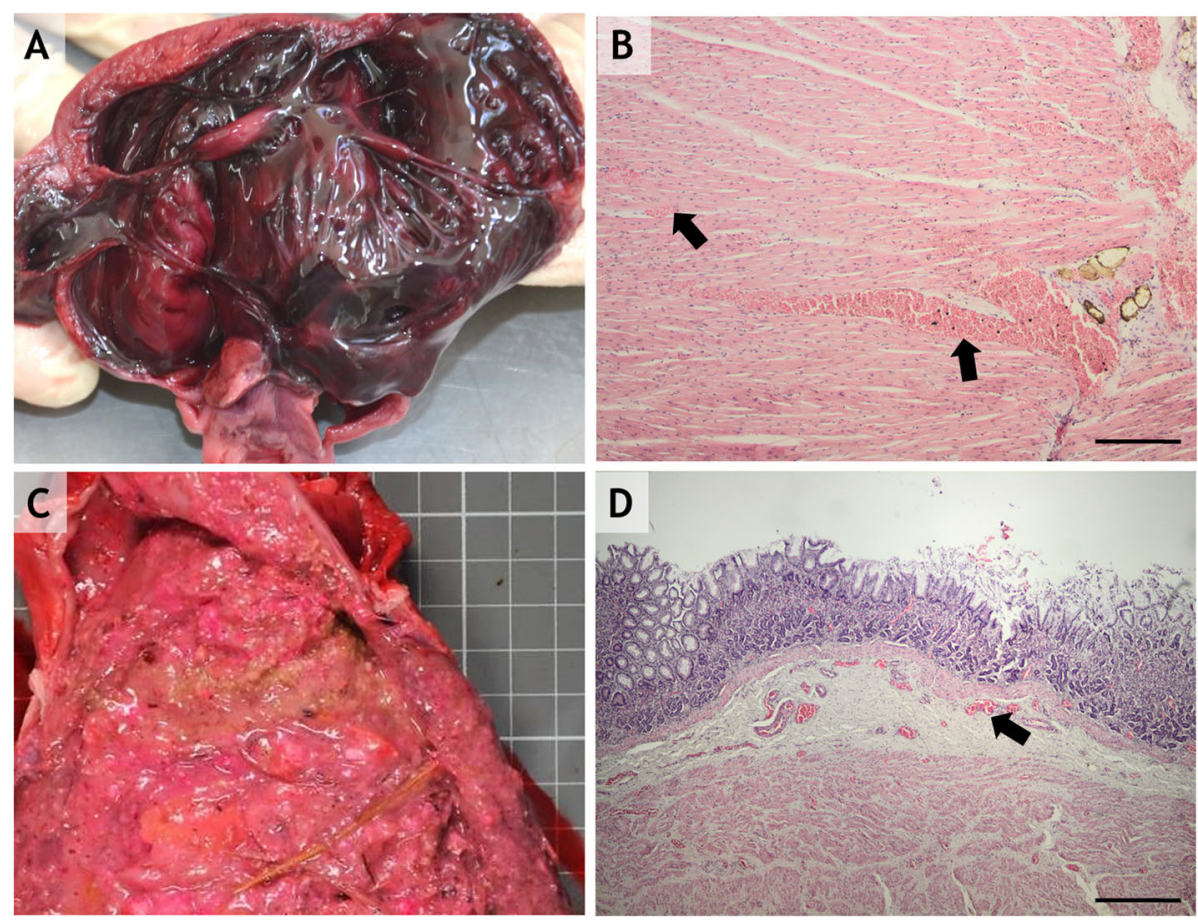

Fig. 2 a Diffuse subendocardial hemorrhages. b: Myocardial congestion and hemorrhage H-E staining, 10x. c: Diffuse gastric congestion and gastric content containing a pink. Foreign substance. d: Diffuse gastric congestion within the lamina propria and submucosa; H-E staining, 10x; scale $\mathrm{bar}=200 \mu \mathrm{m}$
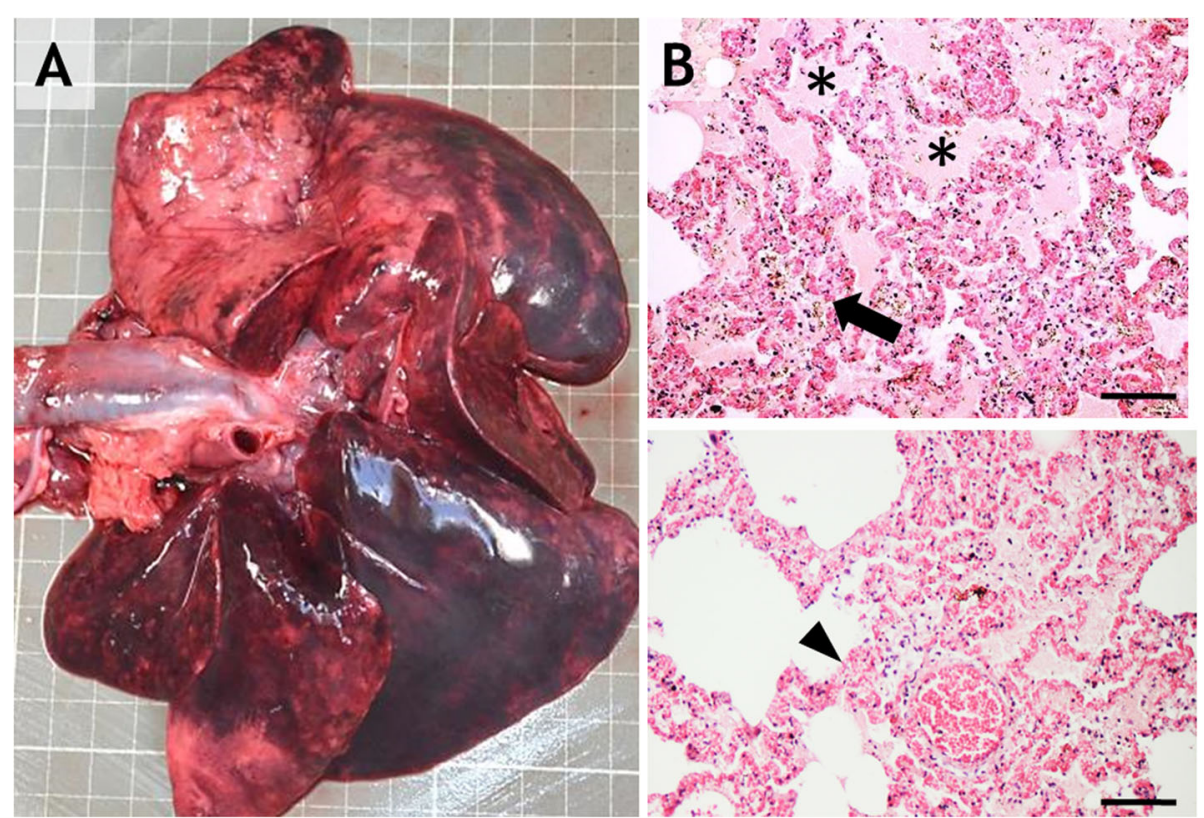

Fig. 3 a: Acute, extensive and bilateral pulmonary congestion, edema, and multifocal hemorrhages. $\mathbf{b}$ and c: Alveolar-septal congestion (arrow), edema (asterisks) and hemorrhage (arrowhead); H-E staining, 20x; scale bar $=100 \mu \mathrm{m}$ 

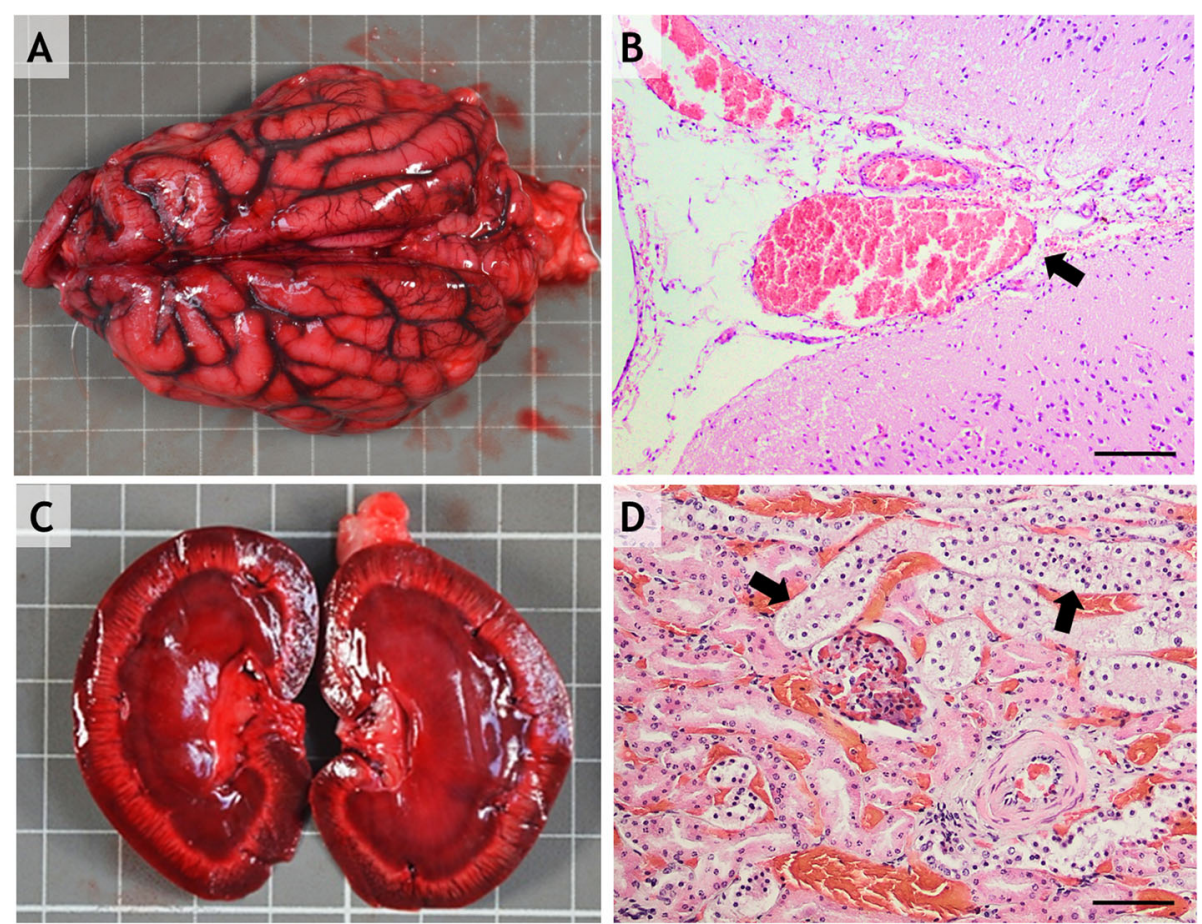

Fig. 4 a: Diffuse subendocardial hemorrhages. b: Myocardial congestion and hemorrhage H-E staining, 10x. c: Diffuse gastric congestion and gastric content containing a pink foreign substance. $\mathbf{d}$ : Diffuse gastric congestion within the lamina propria and submucosa; $\mathrm{H}-\mathrm{E}$ staining, 10x; scale bar $=200 \mu \mathrm{m}$

authorities in legal investigations. According to police report information, there are common reasons for killing both dogs and cats, many of which are related to domestic or social violence [33-35].

The investigation of cases of intentional animal poisoning is as serious as that in human cases [36, 37], yet it is a very challenging and difficult process [15].

The inquiry of an incident that has as result the sudden death of animals generally starts with a field investigation, full gross post-mortem examination, and finally, if considered relevant for the case chemical-toxicological testing for toxin identification [38]. Multistage mass spectrometry (MS/MS) when coupled with chromatography can identify low levels of an analyte in case of pesticide poisoning [39]. Due to the previously reported high sensitivity and selectivity of the analytical determination in case of pesticide intoxication [39] a triple quadrupole mass spectrometry analyzer operated in the selective reaction monitoring mode, was used for our chemical toxicological investigation. The main differences of protocol compared with the technique optimized by Luzardo et al. [39], was the type of matrix (they used liver) and the weight ( $2 \mathrm{~g}$ of sample) of the samples, as well as the dilutions and the quantity of the solvent. Similarly, the use of sonication should be mentioned, which improves the extraction efficiency and recovery rate of certain key pesticides, such as carbofuran.
Therefore, Luzardo et al. [39] added a 5-min sonication to the extraction protocol; in our cases, sonication was performed for $15 \mathrm{~min}$. Another method using $2 \mathrm{~g}$ of homogenized liver samples is based on a new analytical multiclass method named the Quick, Easy, Cheap, Rugged and Safe (QuEChERS) technique [40], developed by Sell et al. and validated according to the requirements of SANCO/12571/2013 [41].

In our study, pathological examinations revealed predominant pulmonary lesions. Thus, carbofuran poisoning induced respiratory and cardiac depression, which led to the death of the dogs. Hyperstimulation affects vascular tone and cell permeability and tissue perfusion [42], which could cause interstitial blood pooling (congestion) and edema. Similar to Motas-Gusman et al. [43], we found acute pulmonary congestion, pulmonary edema, and emphysema but without constriction or bronchial rupture. Pulmonary hemorrhage is typically described, especially in acute intoxication cases [11], and these lesions were also present in our study. Novotny et al. [23] reported dried saliva around the oral cavity, congestion of the organs and hemorrhagic necrosis of the small gut. In our study, we found only one dog with foamy salivation; four dogs presented epistaxis and four had staining by a pink-colored foreign substance (interpreted as being the consumed carbofuran) around the oral cavity. In 6 cases, we observed ocular changes 
consisting of conjunctival hemorrhages or congestion and unilateral or bilateral hyphema (Table 1).

\section{Conclusions}

Currently, although some carbamates have been banned in the European Union, carbamate poisoning is still encountered, especially in wild animals [44] In this study, we described the gross and histopathological changes present in 7 dogs with acute carbamate poisoning. The most frequently encountered changes were located within the respiratory system and were represented by diffuse tracheal congestion, pulmonary congestion, hemorrhage, and edema. Additionally, meningeal cerebral congestion and hemorrhage along with renal congestion, diffuse hepatic and splenic congestion were frequently observed. In some cases, a pink foreign substance was found on the muzzle and on the fur. According to the bait examination and toxicological results, this was interpreted as being the carbofuran-containing poison. This observation could be an indication of furadan intoxication for clinicians, especially if it is associated with suggestive clinical signs or sudden death in the animals.

\section{Methods}

The seven cases (Table 2.) of intentional carbofuran poisoning included in this study were identified in the archives of the Pathology Department of the University of Agricultural Sciences and Veterinary Medicine ClujNapoca, Romania. All cases were submitted for pathological diagnosis between 2015 and 2017, and all of the cases had a registered number from the Pathology Department of the University of Agricultural Sciences and Veterinary Medicine Cluj-Napoca, Romania, where all of the data is located. In four cases, the local authority requested detailed investigations, and in the remaining three cases, the animals were submitted for necropsy by their owners.

This study was approved by the institutional ethics committee, the "Comisia de Bioetica", of the University of Agricultural Sciences and Veterinary Medicine Cluj-Napoca.

In all the cases, the clinical history and the pathological and toxicological findings (including the examination of the bait) were reviewed.
The baits were found near the animals or in the gastric contents and presented a pink color; most baits consisted of a mixture of bread or different kinds of meat (sheep or chicken meat or viscera, including feathers).

A complete postmortem necropsy and histopathology examination were performed in all the cases less than $24 \mathrm{~h}$ after death.

For the histological examination, samples were fixed in $10 \%$ buffered neutral formalin and routinely embedded in paraffin, and 4- $\mu \mathrm{m}$ sections were prepared and stained with hematoxylin-eosin (H-E).

During the necropsy, samples of the gastric content and from the baits were collected and submitted for toxicological examination.

In this study, the toxicological examination was performed by gas chromatography coupled with triple quadrupole mass spectrometry (GC-MS/MS) using solid (bait) and liquid samples (gastric content) [26, 45]. In all the cases, the samples indicated carbofuran intoxication.

The analysis was conducted by the national reference laboratory of the National Sanitary Veterinary and Food Safety Agency of Romania in Cluj-Napoca using standard Romanian methods: SR EN 1528-2:2003 and SR EN 1528-1,3,4:2004 [45, 46] which use as reference documents: Regulation (EC) No 396/2005 of the European Parliament and of the Council of 23 February 2005 on maximum residue levels of pesticides in or on food and feed of plant and animal origin and amending Council Directive 91/414/EECText with EEA relevance; 2002/ 657/EC: Commission Decision of 12 August 2002 implementing Council Directive 96/23/EC concerning the performance of analytical methods and the interpretation of results and SANCO/2004/2726-rev 4-December 20,081 Guidelines for the implementation of decision 2002/657/EC 2. The validation parameters were: linearity, selectivity, limit of detection (LOD, $3 \mu \mathrm{g} / \mathrm{kg}$ ), limit of quantitation (LOQ, $10 \mu \mathrm{g} / \mathrm{kg}$ ), recovery, repeatability, reproducibility, stability, robustness and matrix effect.

For the toxicological exam, 5-g samples were extracted by acetone, homogenized after adding methylene chloride and ethyl acetate and centrifuged. The whole organic extract was evaporated to dryness under gentle nitrogen

Table 2 Case histories and clinical findings

\begin{tabular}{|c|c|c|c|c|c|c|}
\hline Case & Age & Sex & Race & Clinical history & Baits Presence & Coloured fur \\
\hline $\mathrm{I}$ & 6 & $\mathrm{~F}$ & Common breed & Vomiting, muscle tremors, death in $1 \mathrm{~h}$ & No & Yes \\
\hline II & $\sim$ & M & Common breed & Acute death & Yes & Yes \\
\hline III & $\sim$ & M & German shephard & Acute death & Yes & No \\
\hline IV & $\sim$ & $\mathrm{F}$ & German shephard & Acute death & Yes & Yes \\
\hline v & $\sim$ & M & Common breed & Acute death & Yes & Yes \\
\hline VI & 4 & M & Common breed & Found dead with foamy saliva & Yes & No \\
\hline VII & 1 & M & Common breed & Acute death & Yes & No \\
\hline
\end{tabular}


stream at about $40{ }^{\circ} \mathrm{C}$ with a nitrogen evaporator. Then, they were quantitatively passed through a gelpermeation purification vial, and a mixture of cyclohexane and ethyl acetate was added. The purified samples were evaporated to dryness under gentle nitrogen stream at about $40^{\circ} \mathrm{C}$ in the nitrogen evaporator. Hexane was added to the residue, and the mixture was stirred, sonicated, centrifuged and then injected into the GC-MS/ MS equipment $[45,46]$.

\section{Abbreviations}

AChE: Acetylcholinesterase; GC-MS/MS: Gas chromatography-multistage mass spectrometry; H-E: Hematoxylin-eosin; QuEChERS: Quick, Easy, Cheap, Rugged and Safe; LOD: Limit of detection; LOQ: Limit of quantitation

\section{Acknowledgments}

This paper was realized with the help of the University of Agricultural Sciences and Veterinary Medicine.

We thank Irina Irimescu for revising the article.

\section{Authors' contributions}

DP drafted the manuscript and coordinated the interpretations. ALN helped write the manuscript and completed the data analysis and interpretation. FT carried out the postmortem examinations and helped with the necropsy analysis. AG was involved in the histopathological data analysis. AO performed the toxicological analyses and revised the manuscript. CM helped to complete the revised article. All authors read and approved the final manuscript.

\section{Funding}

This project was funded by the Ministry of Research and Innovation through Program 1 - Development of the National Research and Development System, Subprogram 1.2 - Institutional Performance - Projects for Financing the Excellence in CDI, Contract No. 37PFE/06.11.2018, project title "Increasing institutional performance through consolidation and development of research directions within the USAMVCN". The funding bodies played no role in the design of the study and collection, analysis, and interpretation of data and in writing the manuscript.

\section{Availability of data and materials}

The data that support the findings of this study are available from the Department of Veterinary Pathology, University of Agricultural Sciences and Veterinary Medicine; the cases have registration numbers. Data are, however, available from the authors upon reasonable request and with the permission of the Department of Veterinary Pathology, University of Agricultural Sciences and Veterinary Medicine.

\section{Ethics approval and consent to participate}

For this study, the authors received approval from the ethics committee, with 188 reference numbers, the "Comisia de Bioetica" of the University of Agricultural Sciences and Veterinary Medicine. The consent obtained from the owners was written.

\section{Consent for publication}

Not applicable.

\section{Competing interests}

The authors declare that they have no competing interests.

\section{Author details}

'Department of Veterinary Toxicology, University of Agricultural Sciences and Veterinary Medicine, 3-5 Mănăştur Street, 400372 Cluj-Napoca, Romania. ${ }^{2}$ Department of Veterinary Pathology, University of Agricultural Sciences and Veterinary Medicine, 3-5 Mănăstur Street, 400372 Cluj-Napoca, Romania. ${ }^{3}$ Department of Veterinary Cell Biology, Histology and Embryology, University of Agricultural Sciences and Veterinary Medicine, 3-5 Mănăștur Street, 400372 Cluj-Napoca, Romania.
Received: 5 December 2019 Accepted: 23 August 2020

Published online: 31 August 2020

\section{References}

1. Plumlee KH. Clinical veterinary toxicology: Mosby; 2004. https://doi.org/10. 1016/B0-323-01125-X/X5001-8.

2. World Health Organization. The WHO recommended classification of pesticides by hazard and guidelines to classification. Geneva; 2009.

3. Ngaio R: Carbofuran and wildlife poisoning. 2012. ePDF 978-1-119-99854-9; Wiley Online Library 978-1-119-99853-2; ePub 978-1-119-95110-0; Mobi 978-1-119-9511-7.

4. Baron RL. A carbamate insecticide: a case study of aldicarb. Environmental Health Perspective. 1994;102:23-7.

5. U.S. Environmental Protection Agency. (Oct. 18). Carbofuran: requests to amend registrations to delete certain uses and final determination with respect to those uses. Fed Regist. 1990;55(202):42266-8.

6. Worthing CR. The pesticide manual: A world compendium. 8th ed. Croydon: The British Crop Protection Council; 1987.

7. Gupta RC. Carbofuran toxicity. J Toxicol Environ Health. 1994;43:383-418.

8. Wang Y, Kruzik P, Helsberg A, Helsberg I, Rausch WD. Pesticide poisoning in domestic animals and livestock in Austria: a 6 years retrospective study. Forensic Sci Int. 2007:169:157-60.

9. U.S. Department of Agriculture, Soil Conservation Service. SCS/ARS/CES Pesticide Properties Database: Version 2.0 (Summary). Syracuse: USDA - Soil Conservation Service; 1990

10. Oros NA, Nagy A-L. Lucrari practice de toxicology generala. Cluj-Napoca: AcademicPres; 2017

11. Gupta RC. Classification and uses of organophosphates and carbamates. In: Gupta RC, editor. Toxicology of organophosphate and carbamate compounds. Amsterdam: Elsevier Academic Press; 2006. p. 5-24.

12. Frazier $K$, Hullinger $G$, Hines M, Liggett A, Sangster L. 162 cases of aldicarb intoxication in Georgia domestic animals from 1988-1998. Vet HumToxicol. 1999:41:233-5.

13. Xavier FG, Righi DA, Spinosa HS. Fatal poisoning in dogs and cats-a 6-year report in a veterinary pathology service. Braz J Vet Res Anim Sci. 2007c;304-309.

14. Byard RW, Boardman W. The potential role of forensic pathologists in veterinary forensic medicine. Forensic Sci Med Pathol. 2011;7:231-2.

15. Cooper JE, Cooper ME. Forensic veterinary medicine: a rapidly evolving discipline. Forensic Sci. Med. Pathol. 2008:4:75-82.

16. Drummer $\mathrm{OH}$, Kennedy B, Bugeja L, Ibrahim JE, Ozanne-Smith J. Interpretation of postmortem forensic toxicology results for injury prevention research. Inj Prev. 2013;19:284-9.

17. Flanagan RJ, Connally G, Evans JM. Analytical toxicology: guidelines for sample collection postmortem. Toxicol Rev. 2005;24:63-71.

18. Munro R. Forensic necropsy. Semin Avian Exot Pet Med. 1998;7:201-9.

19. Wyman JF. Principles and procedures in forensic toxicology. Clin Lab Med. 2012:32:493-507.

20. Chatelain D, Hebert A, Trouillet N, Charfi S, Stephens P, Manaouil C, Defouilloy C, Braconnier L, Jarde O, Sevestre H. Effectiveness of histopathologic examination in a series of 400 forensic autopsies. Ann Pathol. 2012:32:4-13

21. Fierro MF. Identification of human remains. In: Spitz WU, editor. Spitz and Fisher's Medicolegal investigation of death: guidelines for the application of pathology to crime investigation. 3rd ed. Springfield, Illinois: Charles $C$ Thomas Pub Ltd; 2005. p. 71-117.

22. Grendon J, Frost F, Baum L. Chronic health effects among sheep and humans surviving an aldicarb poisoning incident. Vet Hum Toxicol. 1994;36: 218-23.

23. Novotny L, Misik L, Honzlova A, Ondracek P, Kuca K, Vavra O, Rachac V, Chloupek P. Incidental poisoning of animals by carbamates in the Czech Republic. J Appl Biomed. 2011. https://doi.org/10.2478/v10136-009-0035-3.

24. Xavier FG, Righi DA, Spinosa HS. Aldicarb toxicology: general, clinic and therapeutic features in dogs and cats. Ciênc Rural; 2007b. p. 1206-11.

25. Bagchi M, Zafra S, Bagchi D. DNA damage, gene expression, and carcinogenesis by organophosphates and carbamates. In: Gupta RC, editor. Toxicology of organophosphate and Carbamate compounds. Amsterdam/ New York: Elsevier Academic Press; 2006. p. 533-48.

26. de Siqueira A, Salvagni FA, Yoshida AS, Goncalves-Junior V, Calefi AS, Fukushima AR, Spinosa HD, Maiorka PC. Poisoning of cats and dogs by the carbamate pesticides aldicarb and carbofuran; 2015. 
27. Garcia SJ, Aschner M, Syversen T. Inter-species variation in toxicity of cholinesterase inhibitors. In: Gupta RC, editor. Toxicology of organophosphate and carbamate compounds. Amsterdam: Elsevier Academic Press; 2006. p. 145-58.

28. Leibson T, Lifshitz M. Organophosphate and carbamate poisoning: review of the current literature and summary of clinical and laboratory experience in southern Israel. Med Assoc J. 2008;10:767-70.

29. Gupta RC. Veterinary toxicology, vol. 140: Elsevier Science Publishing; 2018 p. 487.

30. Jung YS, Kim CS, Park HS, Sohn S, Lee BH, Moon CK, Lee SH, Baik EJ, Moon $\mathrm{CH}$. N-nitrosocarbofuran induces apoptosis in mouse brain microvascular endothelial cells (bEnd.3). J Pharmacol Sci. 2003;93:489-95.

31. Yavuz T, Delibas N, Yildirim B, Altuntas I, Candir O, Cora A, Karahan N, Ibrisim E, Kutsal A. Vascular wall damage in rats induced by organophosphorus insecticide methidathion. Toxicol Lett. 2005;155:59-64.

32. Osweiler GD. Organophosphorus and carbamate insecticides. In: Toxicology. Philadelphia: Williams \& Wilkins; 1996. p. 231-6.

33. Arkow P. Child abuse, animal abuse, and the veterinarian. J Am Vet Med Assoc. 1994;204:1004-7.

34. Ascione FR, Shapiro K. People and animals, kindness and cruelty: research directions and policy implications. J Soc Issues. 2009;65:569-87.

35. Degue S, Dilillo D. Is animal cruelty a "red flag" for family violence? Investigating co-occurring violence toward children, partners, and pets. J Interpers Violence. 2009:24:1036-56

36. Merck MD. Crime scene investigation. In: Merck MD, editor. Veterinary forensics: animal cruelty investigations. lowa: Wiley-Blackwell; 2012. p. 19-30.

37. Newbery, S., Munro, R. Forensic veterinary medicine: 1. Investigation involving live animals. Practice, 2011; 220-227.

38. Brown PM, Turnbull G, Charman S, Charlton AJ, Jones A. Analytical methods used in the United Kingdom wildlife incident. Investigation Scheme for the detection of animal poisoning by pesticides. J AOAC Int. 2005;88:204-20.

39. Luzardo OP, Ruiz-Suarez N, Valeron PF, Camacho M, Zumbado M, Henriquez-Hernandez LA, et al. Methodology for the identification of 117 pesticides commonly involved in the poisoning of wildlife using GC-MS-MS and LC-MS-MS. J Anal Toxicol. 2014;38:155-63.

40. Sell B, Sniegocki T, Zmudzki J, Posyniak A. Development of an analytical procedure for the determination of multiclass compounds for forensic veterinary toxicology. J Anal Toxicol. 2017;42(3):183-91.

41. SANCO/12571/2013. Guidance Document on Quality Control and Validation Procedures for Pesticide Residues Analysis in Food and Feed. www.eurl pesticides.eu/library/docs/allcrl/ AqcGuidance_Sanco_2013_12571.pdf. 4-C12.

42. de Siqueira A, de Albuquerque MF, Marlet FE, Maiorka PC. Non-accidental injuries found in necropsies of domestic cats: a review of 191 cases. J Feline Med Surg. 2012;14:723-8

43. Motas-Gusman M, Marla-Mojica P, Romero D, Martinez-Lopez E, GarciaFernandez AJ. Intentional poisoning of animals in southeastern Spain: a review of the veterinary toxicology service from Murcia, Spain. VetHum Toxicol. 2003:45:47-50

44. Ruiz-Suárez N, Boada LD, Henríquez-Hernández LA, GonzálezMoreo F, Suárez-Pérez A, Camacho M, et al. Continued implication of the banned pesticides carbofuran and aldicarb in the poisoning of domestic and wild animals of the Canary Islands (Spain). Sci Total Environ. 2015;505:1093-9.

45. SR EN 1528-1, 3, 4:2004. 1-https://magazin.asro.ro/ro/standard/94017; 394016; 4-94019.

46. SR EN 1528-2:2003. https://magazin.asro.ro/ro/standard/72933.

\section{Publisher's Note}

Springer Nature remains neutral with regard to jurisdictional claims in published maps and institutional affiliations.

Ready to submit your research? Choose BMC and benefit from:

- fast, convenient online submission

- thorough peer review by experienced researchers in your field

- rapid publication on acceptance

- support for research data, including large and complex data types

- gold Open Access which fosters wider collaboration and increased citations

- maximum visibility for your research: over $100 \mathrm{M}$ website views per year

At $\mathrm{BMC}$, research is always in progress.

Learn more biomedcentral.com/submissions 